\title{
DNA fingerprints of Helicobacter pylori before and after treatment with omeprazole
}

\author{
A G Fraser, J Bickley, R J Owen, R E Pounder
}

\begin{abstract}
Aims: To test whether a hypoacidic environment may potentially "stress" Helicobacter pylori DNA, encouraging the emergence of strain variation.

Methods: This hypothesis was tested by inducing prolonged hypoacidity with omeprazole, a potent antisecretory drug. The genomic DNA of $H$ pylori was studied by electrophoretic separation of restriction endonuclease fragments followed by rRNA gene hybridisation in seven patients infected with $H$ pylori before and after treatment with omeprazole $20-40 \mathrm{mg}$ daily for six to eight weeks. DNA was isolated and purified using the guanidium thiocyanate reagent method. DNA samples were digested with Hae III, electrophoresed, vacublotted, and hybridised using a biotinylated cDNA probe prepared from $16 S$ and $23 S$ rRNA from $H$ pylori NCTC 11638. Isolates were compared using their ribopatterns (DNA fingerprints).

Results: A total of 26 isolates were obtained; all DNA isolates were cut by Hae III, which was the enzyme that gave the best resolved hybridisation patterns for analysis. No two patients harboured the same strain. The isolates from two patients showed evidence of subtypic variation; one patient had two distinct strains and four patients had their own indistinguishable strains before and after treatment with omeprazole. For each patient, the paired ribopatterns of $H$ pylori DNA were not affected by treatment with omeprazole for six to eight weeks.

Conclusion: The $H$ pylori genome is relatively stable when exposed to the conditions of prolonged hypoacidity that result from treatment with omeprazole.
\end{abstract}

Royal Free Hospital School of Medicine, London

A G Fraser

R E Pounder

National Collection of Type Cultures, Central Public Health

Laboratory, London

J Bickley

R J Owen

Correspondence to:

Professor RE Pounder MA

MD FRCP, University

Department of Medicine

Department of Medicine,

Royal Free Hospital Schoo

of Medicine, Rowland Hill

Strect

Accepted for publication

30 October 1991

Helicobacter pylori is a microaerophilic rium frequently found in the gastric antrum of both asymptomatic subjects and those with peptic ulcer disease. ${ }^{12}$ Recent work has shown that ${ }^{35} \mathrm{~S}$-methionine-labelled protein sodium dodecyl sulphate-polyacrylamide acrylamide gel electrophoresis (SDS-PAGE), immunoblot and DNA fingerprinting based on DNA digest patterns can all be used to indentify $H$ pylori. ${ }^{3}$ However, ribopatterns provide a simpler, reproducible and sensitive method of discriminating between isolates of $\mathrm{H}$ pylori. ${ }^{4} \mathrm{~A}$ high level of genomic heterogeneity has been shown among $H$ pylor $i$ isolated from different patients in the United Kingdom, the Netherlands, Australia and Canada. ${ }^{4-11}$ This genomic heterogeneity is more pronounced in $H$ pylori than in many other organisms that have been studied, ${ }^{12-14}$ hence the technique of DNA fingerprinting has clear applications for epidemiological research.

The reason for the genetic heterogeneity in $H$ pylori isolates is unclear. Although $H$ pylori DNA fingerprints are highly stable in the laboratory, $H$ pylori may exhibit genetic instability in vivo. Acute infection seems to be associated with a transient achlorhydria: the evidence comes from self ingestion studies ${ }^{15}$ and from retrospective analysis of epidemics of achlorhydria in experimental laboratories which may have been due to transmission of $H$ pylori by contaminated nasogastric tubes. ${ }^{16} 19$ In contrast, the acid secretion of asymptomatic volunteers found to be positive for $H$ pylori on screening (who are likely to have been infected for several years) is normal. ${ }^{20}$ The mechanism of this transient achlorhydria is unknown, certain strains of $H$ pylori can cause profound suppression of acid secretion in isolated human gastric glands. ${ }^{21}$ Achlorhydria causes a luminal bacterial overgrowth which may facilitate the formation of $\mathrm{N}$-nitrosamine compounds ${ }^{22}$ which may damage the DNA of the original infecting $H$ pylori.

This hypothesis was tested in this study by inducing acid suppression with omeprazole. Omeprazole $30 \mathrm{mg}$ daily decreases mean 24 hour intragastric acidity by $97 \%,{ }^{23}$ an effect that is present both day and night. Omeprazole has been very effective in the treatment of duodenal ulceration and ulcerative oesophagitis that is resistant to standard doses of $\mathrm{H}_{2}$-receptor antagonists, ${ }^{24}$ an effect directly related to its profound acid suppression. ${ }^{25}$ Omeprazole has been shown to increase the $\mathrm{N}$-nitrosamine concentration of the gastric juice after two weeks treatment in healthy volunteers. ${ }^{26}$ Patients treated with this drug may therefore be a valid model in which to test the hypothesis.

\section{Methods}

Patients presenting for endoscopic investigation of their dyspepsia were identified as being infected with $H$ pylori and requiring omeprazole treatment, because of either failure to respond to treatment with $\mathrm{H}_{2}$-receptor antagonists or because of aggressive duodenal ulceration or reflux oesophagitis. Patients taking 
bismuth, antibiotics, or omeprazole within the previous six weeks were excluded. From these patients, biopsy specimens for culture of $H$ pylori were taken from at least two different sites in the antrum. Follow up biopsy specimens were taken one week after completing a six to eight week course of omeprazole 20 or $40 \mathrm{mg}$ daily.

\section{$H$ pylori CULTURE}

The biopsy specimens for culture were placed directly in a selective enrichment medium. This consisted of Brucella broth (Difco Laboratories, East Molesey, Surrey, England) supplemented with $10 \%$ fetal calf serum, $1 \%(\mathrm{v} / \mathrm{v})$ Isovitalex (BBL Microbiology Systems, Becton Dickinson, Cowley, Oxford), polymyxin B 1000 Units $/ \mathrm{ml}$, vancomycin $10 \mu \mathrm{g} / \mathrm{ml}$, and amphotericin B $2 \mu \mathrm{g} / \mathrm{ml}^{26}{ }^{27}$ Specimens were transported to the microbiology laboratory within three hours. Each biopsy specimen was then placed in $5 \mathrm{ml}$ of selective enrichment medium in a $100 \mathrm{ml}$ conical flask. The flasks were incubated at $37^{\circ} \mathrm{C}$ on a gyratory platform in a variable atmosphere incubator (Don Whitley Scientific Ltd, Shipley, Yorks), under microaerobic conditions ( $5 \%$ oxygen, $5 \%$ carbon dioxide, $2 \%$ hydrogen, $88 \%$ nitrogen). A sample from each flask was subcultured on to Oxoid brain-heart infusion agar, supplemented with $5 \%$ horse blood and $1 \%$ Isovitalex, after 48 hours. Positive growth was identified by Gram stain and production of urease, and cultures were preserved at $-196^{\circ} \mathrm{C}$ on glass beads in Oxoid nutrient broth No 2 (Oxoid, Basingstoke) containing $10 \%(\mathrm{v} / \mathrm{v})$ glycerol. Seven patients had at least one positive culture from before and after treatment, and these isolates were analysed using their ribopatterns.

DNA ISOLATION, DIGESTION AND ELECTROPHORESIS, VACUBLOTTING AND RRNA GENE HYBRIDISATION

Chromosomal DNA samples from isolates of
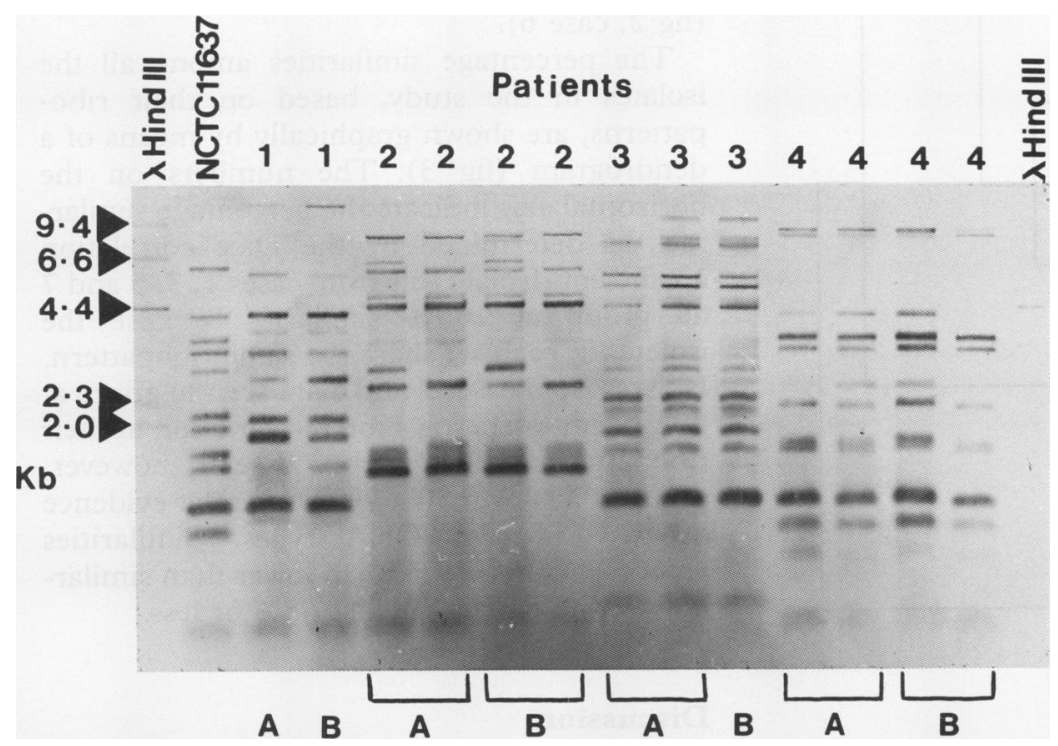

Figure 1 The rRNA gene patterns (ribopatterns) for Hae III digests of chromosomal DNA from multiple isolates of $H$ pylori from cases $1-4$. DNA digests were probed with biotinylated $c D N A$ from $H$ pylori NCTC 11638. Isolates are labelled to indicate whether they were obtained before $(B)$ or after $(A)$ treatment with omeprazole. Sizes indicated are for bacteriophage $\lambda$ Hind III digest and H pylori NCTC 11637 (type strain) was included as a reference.
DNA band size windows used for numerical analysis of Hae III ribopatterns

\begin{tabular}{|c|c|c|}
\hline $\begin{array}{l}\text { Band window } \\
\text { (locus) }\end{array}$ & $\begin{array}{l}\text { Size range } \\
\text { (kilobases) }\end{array}$ & $\begin{array}{l}\text { Number and percentage of strains } \\
\text { with ribopatterns containing the } \\
\text { band }\end{array}$ \\
\hline $\begin{array}{r}1 \\
2 \\
3 \\
4 \\
5 \\
6 \\
7 \\
8 \\
9 \\
10 \\
11 \\
12 \\
13 \\
14 \\
15 \\
16 \\
17 \\
18 \\
19 \\
20 \\
21\end{array}$ & 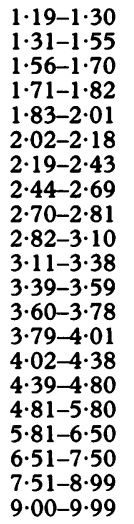 & $\begin{array}{c}11(42) \\
17(65) \\
6(23) \\
19(73) \\
16(62) \\
7(27) \\
17(65) \\
19(73) \\
6(23) \\
11(42) \\
8(31) \\
15(58) \\
2(8) \\
0(0) \\
20(77) \\
11(42) \\
7(27) \\
11(42) \\
6(23) \\
11(42) \\
8(31)\end{array}$ \\
\hline
\end{tabular}

$H$ pylori were prepared using the guanidium thiocyanate reagent method ${ }^{28}$ and were incubated with the restriction enzyme, HaeIII, to produce DNA restriction digestion patterns. Twenty six isolates were obtained from the culture of biopsy specimens from the antrum, body and duodenum of the patients in this study, and NCTC 11637 (National Collection of Type Cultures strain) was also included as a reference on all gels. DNA samples $(5 \mu \mathrm{g})$ were digested for four hours at $37^{\circ} \mathrm{C}$ and the digested DNA was then electrophoresed at $30 \mathrm{~V}$ for 16 hours in a horizontal $0.8 \%(\mathrm{w} / \mathrm{v})$ agarose gel. After electrophoresis the gels were stained with ethidium bromide and photographed for a permanent record.

Agarose gel electrophoresis of all isolates was followed by transfer of the digested DNA on to nylon membranes (Hybond-N, Amersham International, Amersham, Bucks) by means of vacublotting (Vacu-Gene XL, Pharmacia LKB Biotechnology, Uppsala, Sweden). A biotinylated cDNA probe was prepared from $H$ pylori NCTC $1163816 S$ and 23S rRNA using Moloney mouse leukaemia virus reverse transcriptase (Gibco-BRL, Paisley, Scotland). Biotinylation was achieved by the incorporation of biotin-16-dUTP. The membranes were then hybridised by standard procedures for 16 hours at $42^{\circ} \mathrm{C}$ using the biotinylated cDNA probe. ${ }^{529}$ The membranes were washed and the hybridised probe detected colorimetrically using a nonradioactive detection kit - BluGENE (Gibco-BRL).

BAND SIZE ESTIMATION AND COMPUTATION OF STRAIN SIMILARITIES

DNA band sizes in the Southern blot hybridisation patterns were calculated from migration distances using an automated gel reader and analysis system (IBI, New Haven, Connecticut, USA). Biotinylated $\lambda$ phage (GibcoBRL) digested with Hind III was used to provide the size markers.

To compare the ribopatterns from all the isolates in the study, the bands were coded according to size to minimise errors when determining similarities between the ribopat- 


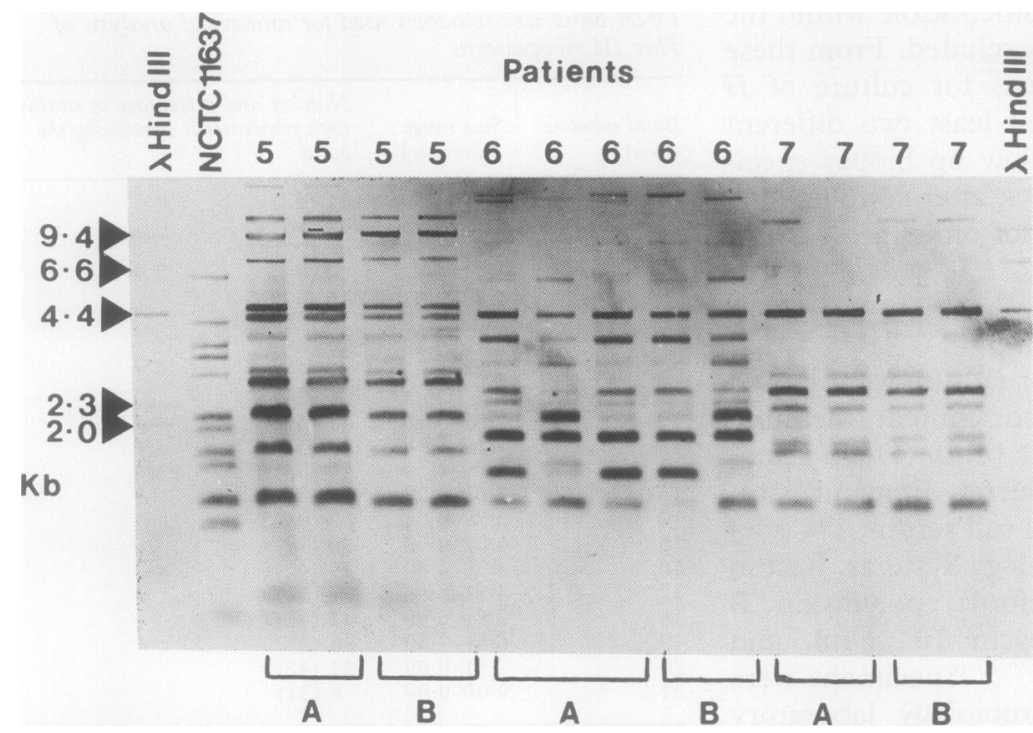

Figure 2 The rRNA gene patterns (ribopatterns) for the Hae III digests of chromosomal $D N A$ from multiple isolates of $H$ pylori from cases 5-7. DNA digests were probed with biotinylated $c D N A$ from $H$ pylori NCTC 11638. Isolates are labelled to indicate whether they were obtained before (B) or after $(A)$ treatment with omeprazole. Sizes indicated are for bacteriophage $\lambda$ Hind III digest and H pylori NCTC 11637 (type strain) was included as a reference.

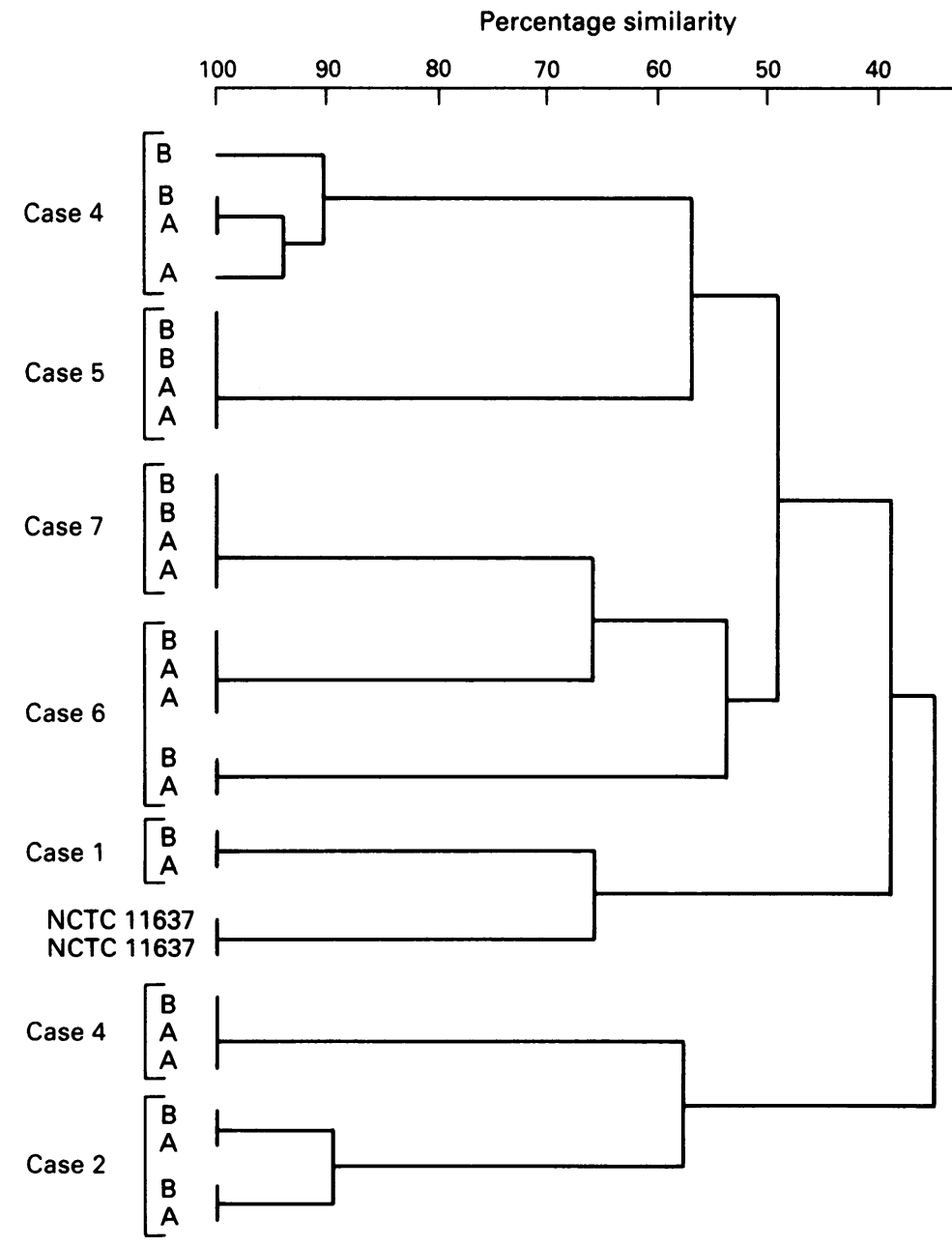

Figure 3 Dendrogram of the cluster analysis to show similarities based on the Hae III ribopatterns of $H$ pylori isolates from cases 1-7, and the type strain NCTC 11637. The numbers on the horizontal axis indicate the percentage similarities as determined by the Dice correlation coefficient. terns by computer assisted methods of analysis. The patterns were screened for bands within 21 different size ranges up to 10 kilobase pairs (table) that were defined by visual inspection, and positive (presence) and negative (absence) results were recorded for each patient isolate. Bands of very faint intensity were excluded and double bands falling within a given range were scored as a single band. Computed similarities among strains were estimated by means of the Dice coefficient (negative matches excluded) and a dendrogram plotted. ${ }^{30} \mathrm{H}$ pylori NCTC 11637 was included as a reference on each gel.

\section{Results}

A total of 26 isolates were obtained from the seven patients; each patient had at least one positive culture before and after treatment. The patients had a median age of 53 years (range 31-71 years); all patients were male. At endoscopy, six of the seven patients had an active duodenal ulcer, one patient had duodenitis and reflux oesophagitis. Three patients had been taking low dose $\mathrm{H}_{2}$-receptor antagonists prior to the study.

DNA from all the isolates was cut by HaeIII, which was the enzyme that gave the best resolved hybridisation patterns for analysis. DNA types were defined on the basis of clearly distinct DNA fingerprints with multiple band differences, whereas DNA subtypes were defined where only one or two bands differed between the ribopatterns of different isolates, and the percentage similarity was at least $90 \%$. Four patients had isolates with identical ribopatterns from all their biopsy specimens (fig 1, cases 1 and 3; fig 2, cases 5 and 7). Two patients had evidence of subtypic variation in the pretreatment biopsy specimens and this variation was also evident after treatment (fig 1 , cases 2 and 4), and one patient had two different strain types which were present both before and after treatment with omeprazole (fig 2, case 6).

The percentage similarities among all the isolates in the study, based on their ribopatterns, are shown graphically by means of a dendrogram (fig 3). The numbers on the horizontal axis indicate the percentage similarities as determined by the Dice correlation coefficient. Isolate sets from cases $1,3,5$ and 7 all group at $100 \%$ similarity because the isolates in each set share the same ribopattern. Isolates from cases 2 and 4 are seen to group at $90 \%$, demonstrating subtypic variation in their ribopatterns. Isolates from case 6 , however, group at just over $50 \%$, showing clear evidence of two different DNA types. Similarities among patients were much lower than similarities within patient sets, at $65 \%$ or less.

\section{Discussion}

This study does not support the hypothesis that achlorhydria can induce changes in the $H$ pylori genome. Omeprazole treatment has a suppressive effect against $H$ pylori; the bacterium is present in lower numbers and is 
difficult to culture while treatment is maintained. ${ }^{3132}$ This effect may be because of a direct bactericidal action, or may be a direct consequence of the profound acid suppression due to bacterial overgrowth changing the microflora and ecological niche of the bacterium. ${ }^{26}$ Omeprazole treatment may not be an ideal model for the transient achlorhydria of acute $H$ pylori infection, because of the drug's possible direct action on the bacterium. Nevertheless, no genomic change was observed after treatment with omeprazole in the present study.

This study does confirm that each unrelated person is infected with a unique strain, or occasionally, strains, of $H$ pylori. Majewski and Goodwin, ${ }^{10}$ Langenberg et $a l^{8}$ and Owen et $a l^{4}$ have also shown unique patterns in each subject of the groups that they examined. Two out of seven patients showed subtypic variation among their isolates, but one patient harboured different strain types of the bacterium. Other studies have also shown that infection with two or more strain types can occur occasionally in a single patient. Prewett et al showed that two of 15 patients were colonised by two different $H$ pylori types ${ }^{20}$ and Beji et al described one patient who had three different $H$ pylori DNA patterns from organisms cultured from three biopsy specimens at one endoscopy. ${ }^{33}$

This study also shows that $H$ pylori isolated from an individual subject at different timesfor example, before and after treatment with omeprazole-usually have the same DNA type. ${ }^{4111}$ The minor subtypic DNA differences that were seen in $H$ pylori isolated from two patients were also stable with time and treatment. DNA digest patterns of $H$ pylori cultures maintained in a laboratory are highly stable. This stability, together with the identical ribotypes obtained before and after treatment, suggests that the subtypic differences are genuine minor genomic variations, possibly representing stable point mutations or inversions.

This study supports the evidence from other studies ${ }^{4}$ that two or more DNA subtypes-or indeed types, as in the case of case 6-can coexist in the gastric mucosa of a patient at any one time. The reason for the pronounced genomic heterogeneity of $H$ pylori remains unclear, but it is unlikely that it is caused by the bacterium's ability to induce transient intragastric hypoacidity.

Ms Doris Elliott typed the manuscript

1 Rathbone BJ, Heatley RV, eds. Campylobacter pylori and gastroduodenal disease. Oxford: Blackwell Scientific Pubgastroduodenal dised
lications, 1989.

2 Blaser MJ, ed. Campylobacter pylori in gastritis and peptic ulcer disease. New York: Igaten-Shoin, 1989.

3 Clayton CL, Kleanthous H, Dent JC, McNulty CAM, Tabaqchali S. Evaluation of fingerprinting methods for identification of Helicobacter pylori strains. Eur f Clin Microbiol Infect Dis 1991;10:1040-7.

4 Owen RJ, Fraser J, Costas M, Morgan D, Morgan DR. Signature patterns of DNA restriction fragments of Helicobacter pylori before and after treatment. $\mathcal{F}$ Clin Pathol 1990;43:646-9.
5 Morgan DD, Owen RJ. Use of DNA restriction endonuclease digest and ribosomal RNA gene probe patterns to fingerprint Helicobacter pylori and Helicobacter mustelae isolated from human and animal hosts. Mol Cell Probes 1990;4:321-34.

6 Owen RJ, Bickley J, Costas M, Morgan DR. Genomic variation in Helicobacter pylori: application to identification of strains. Scand $尹$ Gastroenterol 1991;26(suppl 181):43-50.

7 Prewett EJ, Bickley J, Owen RJ, Pounder RE. Deoxyribonucleic acid patterns of Helicobacter pylori isolated from gastric antrum, body and duodenum. Gastroenterology 1992;102:829-33.

8 Langenberg W, Rauws EAJ, Widjojokusumo A, Tytgat GNJ Zanen HC. Identification of Camplyobacter pyloridis isolates by restriction endonuclease DNA analysis. 7 Clin Microbiol 1986;24:414-17.

9 Oudbier JH, Langenberg W, Rauws EAJ, Bruin-Mosch C. Genotypical variation of Campylobacter pylori from gastric mucosa. 7 Clin Microbiol 1990;28:559-65.

10 Majewski SIH, Goodwin CS. Restriction endonuclease analysis of the genome of Campylobacter pylori with a rapid extraction method: evidence for considerable genorapid extraction method: evidence for considera

11 Simor AE, Shames B, Drumm B, Sherman P, Low DE, Penner JL. Typing of Campylobacter pylori by bacteria DNA restriction endonuclease analysis and determination of plasmid profile. $\mathcal{F}$ Clin Microbiol 1990;28:83-6.

12 Soto A, Pitcher DG, Soriano F. A numerical analysis of ribosomal RNA gene patterns for typing clinical isolates of Corynebacterium group D2. Epidemiol Infect 1991;107:263-72.

13 Martinetti G, Altwegg M. rRNA gene restriction patterns and plasmid analysis as a tool for typing Salmonella and plasmid analysis as a tool for typing

14 Koblari S, Grimont F, Grimont PAD. Clonal diversity of Vibrio Cholerae 01 evidenced by rRNA gene restriction patterns. Res Microbiol 1990;141:645-57.

15 Morris A, Nicholson G. Ingestion of Campylobacter pyloridis causes gastritis and raised fasting gastric $\mathrm{pH}$. $\mathrm{Am} \mathfrak{f}$ Gastroenterol 1987;82:192-9.

16 Petersen W, Lee E, Skoglund M. The role of Campylobacter pyloridis in epidemic gastritis with hypochlorhydria. Gastroenterology 1987;92:1575.

17 Harford W, Barnett C, Lee E, Cohen R, Mertz H, Walsh J, Peterson W. Epidemic gastritis with hypochlorhydria: 10 years follow-up. Gastroenterology 1991;101:A79.

18 Graham DY, Smith JL, Albert LC, Yoshimure HH. Iatrogenic Campylobacter pylori infection is a cause of genic Campylobacter pylori infection is a cause of epidemic

19 Hunt RH. Campylobacter pylori and spontaneous hypochlorhydria. In: Rathbone BJ and Heatley RV, ed. Campylobacter pylori and gastroduodenal disease. Oxford: Blackwell Scientific Publications, 1989:176-84.

20 Prewett EJ, Smith JTL, Nwokolo CU, Hudson M, Sawyer AM, Pounder RE. Eradication of Helicobacter pylori abolishes 24-hour hypergastrinaemia in a prospective study in healthy subjects. Aliment Pharmacol Ther 1991;3:283-90.

21 Jablonowski H, Kramer N, Hengels KJ. Effect of Helicobacter pylori on acid secretion by isolated human cobacter pylori on acid secretion by isolated
gastric glands. Gastroenterology 1991;101:A70.

22 Walter CL. Gastric juice N-nitrosocompounds. In: Reed PI, Hill BMJ, eds. Gastric Carcinogenesis. Amsterdam: Elsevier, 1988:163-73.

23 Sharma BK, Walt RP, Pounder RE, Gomes M de FA, Wood EC, Logan LH. Optimal dose of oral omeprazole for maximal 24-hour decrease of intragastric acidity. Gu 1984;25:957-64.

24 Maton M. Omeprazole. N Engl f Med 1991;324:965-75.

25 Burget DW, Chiverton SG, Hunt RH. Is there an optima degree of acid suppression for healing of duodenal ulcers? Gastroenterology 1990;99:345-51.

26 Sharma BK, Santana IA, Wood EC, et al. Intragastric bacterial acidity and nitrosation before, during and after omeprazole treatment. Br Med f 1984;289:771-9.

27 Morgan DR, Mathewson JJ Freedman R, Kraft WG Evaluation of a selective enrichment technique for the Evaluation of a selective enrichment technique for the
isolation of Campylobacter pylori. FEMS Microbiol Lett isolation of Camp $1990 ; 66: 303-6$.

28 Pitcher DG, Saunders NA, Owen RJ. Rapid extraction of bacterial genomic DNA with guanidium thiocyanate. Let Appl Microbiol 1989;8:151-6.

29 Owen RJ, Costas M, Dawson C. Application of different chromosomal DNA restriction digest fingerprints to specific and subspecific identification of Campylobacter isolates. $\mathcal{f}$ Clin Microbiol 1989;27:2338-43.

30 Owen RJ, Bickley J, Lastovica AL, Dunn JP, Borman P, Hunton C. Ribosomal RNA gene patterns of Helicobacter pylori from surgical patients with healed and recurrent peptic ulcers. Epidemiol Infect 1991;108:39-50.

recurrent peptic ulcers. Epidemiol Infect 1991;108:39-50.
31 Weil J, Bell GD, Powell K, et al. Omeprazole and Helicobacter pylori: temporary suppression rather than the cobacter pylori: temporary suppression rather than the
true eradication. Aliment Pharmacol Ther 1991;3:309-12.

32 Rauws EAJ, Langenberg W, Bosma A, Dankert J, Tytgat GNJ. Lack of eradication of Helicobacter pylori after GNJ. Lack of eradication of Helico

33 Beji A, Vincent P, Darchis I, Husson MO, Cortot A, Leclerc H. Evidence of gastritis with several Helicobacter pylori strains. Lancet 1989;ii:1402-3. 